\title{
The Effect of Hydrogen Bonding and Azomethine Group Orientation on Liquid Crystal Properties in Benzylidene Aniline Compounds
}

\author{
Abdullah Hussein Kshash \\ Department of Chemistry, Education College for Pure Science, University Of Anbar, 31001, Ramadi, Anbar, Iraq \\ *Corresponding author: E-mail:fdrabdullahkshash@gmail.com \\ Tel: +964-7830818171
}

Received: 10-25-2019

\begin{abstract}
This study examines the effects of substituents and hydrogen bonding, orientations of imine linkage on the behavior of benzylidene aniline compounds as liquid crystals (LC). Compounds 4-carboxy benzylidene-4-X-aniline (X = H, F, Cl, $\left.\mathrm{Br}, \mathrm{CH}_{3}, \mathrm{OCH}_{3}\right) \mathbf{1 a}-\mathbf{6 a}$ were synthesized by the reaction of aniline and its substituted derivatives with 4-formylbenzoic acid. Compounds 4-X-benzylidene-4-carboxy aniline $\left(\mathrm{X}=\mathrm{H}, \mathrm{F}, \mathrm{Cl}, \mathrm{Br}, \mathrm{CH}_{3}, \mathrm{OCH}_{3}\right) \mathbf{1 b}-\mathbf{6 b}$ were synthesized by the reaction of benzaldehyde and its substituted derivatives with 4-aminobenzoic acid using absolute ethanol as the solvent. Synthesized compounds were characterized by FT IR and ${ }^{1} \mathrm{H}$ NMR spectroscopy, liquid crystal properties were investigated using differential scanning calorimetry (DSC) and polarizing optical microscopy (POM) techniques. Based on the mesomorphic properties, it was proven that the compounds $\mathbf{2 b}-\mathbf{4 b}$ are dimorphic exhibiting a smectic and nematic phase, compounds $\mathbf{5 b} \mathbf{6} \mathbf{6} \mathbf{b}$ are monomorphic exhibiting a nematic phase, while compounds $\mathbf{1 a}-\mathbf{6} \mathbf{a}$ and $\mathbf{1 b}$ have not shown any mesophase. For compounds 1a-6a hydrogen bonding and reversing imine linkage (in comparison with compounds $\mathbf{1 b}-\mathbf{6 b}$ ) caused the absence of their mesomorphic properties.
\end{abstract}

Keywords: Benzylideneaniline, liquid crystals, hydrogen bonding, nematic phase, smectic phase, 4-formylbenzoic acid.

\section{Introduction}

Molecules of liquid crystals (LCs) with low molecular masses consist of a central core, generally containing phenyl rings linked by a double bond(s) and terminal groups such as alkyl and alkoxy chains, which promote molecular crystallinity and lower melting points. ${ }^{1}$

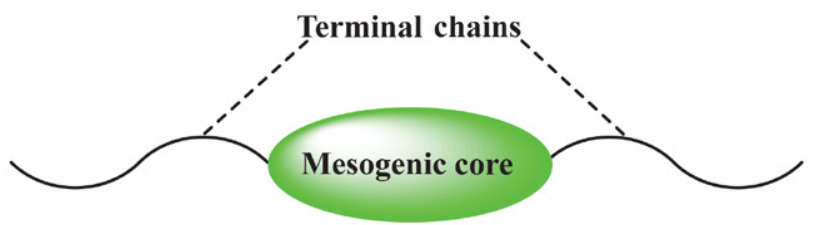

Hydrogen bonding is an intermolecular attractive interaction between the hydrogen atom of a molecule $\mathrm{X}-\mathrm{H}$, where $\mathrm{H}$ is less electronegative than $\mathrm{X}$, and a $\mathrm{Y}$ atom that possesses one pair of electrons in the same or another molecule, therefore, hydrogen bond donor is $\mathrm{X}-\mathrm{H}$, and the acceptor is $\mathrm{Y}$ or a $\pi$-bond. Three-dots symbol $(\cdots)$ is usually used to depict the hydrogen bonding, such as $\mathrm{X}-$
$\mathrm{H}$... Y-Z, where both atoms $\mathrm{X}$ and $\mathrm{Y}$ could be F, $\mathrm{O}$ and N.,3 The association of some molecules via hydrogen bonding enhances the mesogenic properties of these molecules by the formation of homodimers, heterodimers, and complex structures. The first enhancement was the homodimerization of $n$-alkoxybenzoic acids 1 and $n$-alkylthio benzoic acids 2 via hydrogen bonding and formation of a supramolecular nucleus. ${ }^{4,5}$

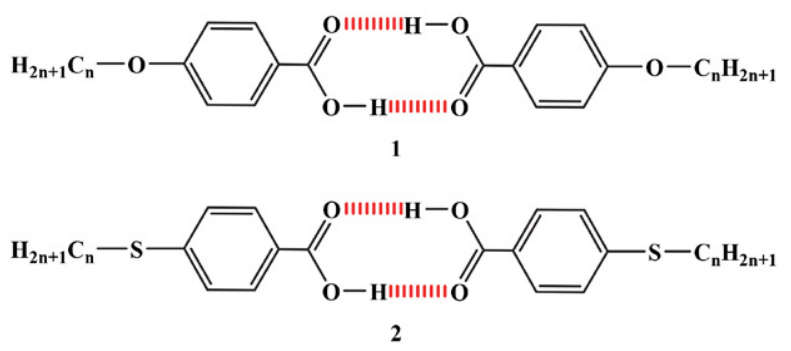

Heterodimerization can occur in different ratios to form supramolecular liquid crystals. For instance, heterocomplex 3 can be obtained in ratio 1:1 via the formation of 
a single hydrogen bond $(\mathrm{H} \cdots \mathrm{N})$ between 4-alkoxybenzoic acid and pyridine fragment. ${ }^{6}$

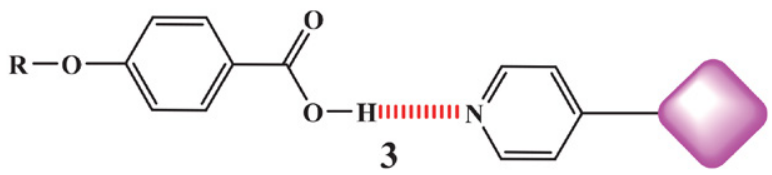

On the other hand, heterocomplex 4 is formed in ratio 2:1 via the formation of two hydrogen bonds between the bipyridyl fragment and two carboxylic acid molecules. ${ }^{7}$

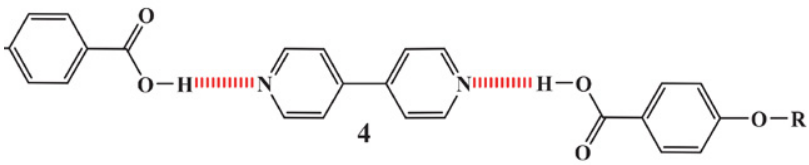

Inverted approaches of ratio 2:1 can also be found, such as in heterocomplex $\mathbf{5}$ between a dicarboxylic acid and two pyridine fragments. ${ }^{8}$

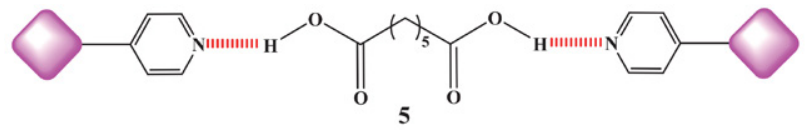

Halogen bonding is defined as an interaction between the halogen atom $\mathrm{X}$ and an electronegative atom $\mathrm{A}$, which is generally depicted by the dotted line: D-X...A. ${ }^{9}$ The electron density around the halogen is polarized and distributed anisotropically and can additionally be amplified when halogen atom is bonded to an electron-withdrawing group. ${ }^{10}$ Nguyen and his colleagues reported that there are no mesomorphic properties of 4-alkoxy-4'-stilbazole 6 .

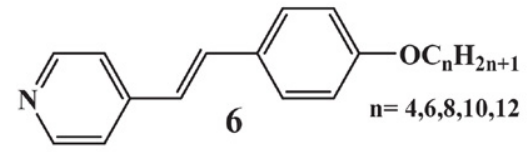

Nevertheless, the mixing of equimolar amounts of stilbazoles $\mathbf{6}$ and pentafluoroiodobenzene can cause interactions between the nitrogen atom in the pyridine ring and the electronic iodine density by forming a halogen bond, that can also induce the formation of complex $\mathbf{7}$ which is exhibiting nematic and smectic phases. ${ }^{11}$

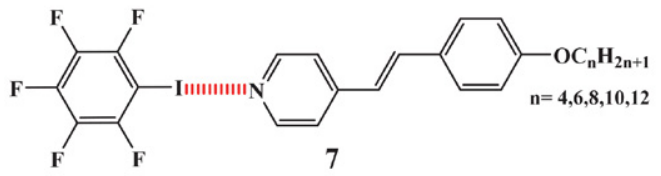

Thus, the anisotropic complex formed by halogen bonding extends the rigid-rod motif for the molecule and induces liquid crystal properties.

Non-planar $N$-benzylidene aniline is the simplest compound of Schiff base structure; torsion angle for $\mathrm{N}$-phenyl bond is around $55^{\circ}$, and about $10^{\circ}$ for the benzylidene ring, so the $\pi$ orbitals of azomethine group are being more parallel to benzylidene ring than to the aniline ring $^{12}$ (Fig. 1).

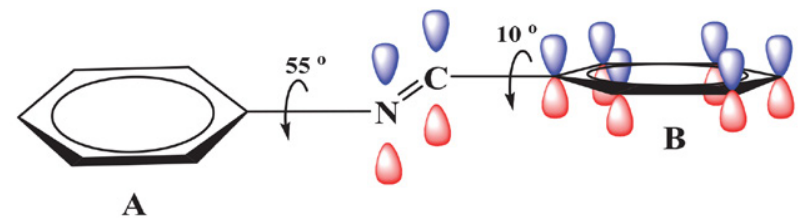

Figure 1. The torsion angle for benzylidene aniline compounds.

This study aims to investigate the influence of hydrogen bonding and the orientation of the imine linkage on liquid crystalline properties of the benzylidene aniline compounds, using 4-carboxy-benzylidene-4- $\mathrm{X}$-aniline $\quad\left(\mathrm{X}-\mathrm{C}_{6} \mathrm{H}_{4}{ }^{-}\right.$ $\left.\mathrm{N}=\mathrm{CH}-\mathrm{C}_{6} \mathrm{H}_{4}-\mathrm{COOH}\right) \mathbf{1 a}-\mathbf{6 a}$ and 4-X-benzylidene-4-carboxy-aniline $\left(\mathrm{X}-\mathrm{C}_{6} \mathrm{H}_{4}-\mathrm{CH}=\mathrm{N}-\mathrm{C}_{6} \mathrm{H}_{4}-\mathrm{COOH}\right) \mathbf{1 b}-\mathbf{6 b}$ as models, where $\mathrm{X}=\mathrm{H}, \mathrm{F}, \mathrm{Cl}, \mathrm{Br}, \mathrm{CH}_{3}, \mathrm{OCH}_{3}$.

\section{Experimental Section}

\section{1. Material and Methods}

All chemicals were purchased from Sigma-Aldrich. They were used without further purification. Infrared spectra were recorded as ATR using Bruker-Tensor 27 spectrometer. ${ }^{1} \mathrm{H}$ NMR spectra were recorded using Bruker $400 \mathrm{MHz}$ spectrometer and DMSO- $d_{6}$ as the solvent. Measurements of phase transition temperatures were made using Mettler Toledo DSC 823 (DSC) at a heating rate of $10^{\circ} \mathrm{C} \mathrm{min}^{-1}$, and POM equipped with hot stage.

\section{2. Synthesis of Schiff Bases}

To a $50 \mathrm{~mL}$ round-bottomed flask, that contains 20 $\mathrm{mL}$ of absolute ethanol, $7 \mathrm{mmol}$ of aromatic aldehyde, and 5 drops of glacial acetic acid, was added $7 \mathrm{mmol}$ of aromatic amine dissolved in $10 \mathrm{~mL}$ of absolute ethanol; the mixture was then refluxed for $3 \mathrm{~h}$, thereafter cooled down to room temperature, the solid precipitate obtained was filtered, washed with cooled EtOH and recrystallized from EtOH.

The compounds of 4-carboxy benzylidene-4-X-aniline (Fig. 2) have been characterized as follows:

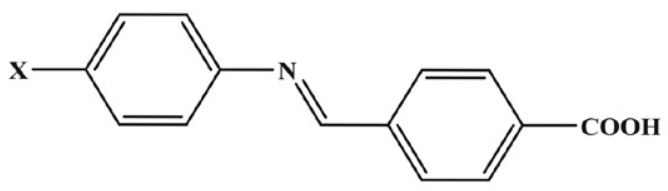

$\mathrm{X}=\mathrm{H}(\mathbf{1 a}), \mathrm{F}$ (2a), $\mathrm{Cl}$ (3a), $\mathrm{Br}(\mathbf{4 a}),-\mathrm{CH}_{3}$ (5a), $-\mathrm{OCH}_{3}$ (6a)

Figure 2. Molecular structure for compounds 1a-6a.

4-Carboxybenzylideneaniline (1a). ${ }^{13}$ White solid, yield 82\%; m.p. $219-221{ }^{\circ} \mathrm{C}$, IR (ATR) cm ${ }^{-1} 2500-3500(\mathrm{O}-\mathrm{H}$ carboxylic acid), 3077 (C-H aromatic), $3032(v \mathrm{H}-\mathrm{CN})$, $1679\left(\mathrm{C}=\mathrm{O}\right.$ carboxylic acid), $1620(\nu \mathrm{C}=\mathrm{N}) .{ }^{1} \mathrm{H}$ NMR: $\delta$ 
13.18 (s, 1H, H-15), 8.73 (s, 1H, H-8), 8.08 (d, $J=8.1 \mathrm{~Hz}$, 2H, H-11, H-13), 8.06 (d, $J=8.3 \mathrm{~Hz}, 2 \mathrm{H}, \mathrm{H}-3, \mathrm{H}-7), 7.45$ (t, $J=7.7 \mathrm{~Hz}, 2 \mathrm{H}, \mathrm{H} 4, \mathrm{H}-6), 7.32$ (d, $J=7.8 \mathrm{~Hz}, 2 \mathrm{H}, \mathrm{H}-10$, $\mathrm{H}-14), 7.29$ (t, $J=7.3 \mathrm{~Hz}, 1 \mathrm{H}, \mathrm{H}-5)$.

4-Carboxybenzylidene-4-fluoroaniline (2a). Pale yellow solid, yield 65\%; m.p. $230-232{ }^{\circ} \mathrm{C}$, IR (ATR) $\mathrm{cm}^{-1} 2500-$ 3500 (O-H carboxylic acid), 3057 (C-H aromatic), 3031 $(v \mathrm{H}-\mathrm{CN}), 1675\left(\mathrm{C}=\mathrm{O}\right.$ carboxylic acid), $1620(\nu \mathrm{C}=\mathrm{N}) .{ }^{1} \mathrm{H}$ NMR: $\delta 13.18$ (s, 1H, H-15), $8.74(\mathrm{~s}, 1 \mathrm{H}, \mathrm{H}-8), 8.08$ (d, $J=$ $8.1 \mathrm{~Hz}, 2 \mathrm{H}, \mathrm{H}-11, \mathrm{H}-13), 8.05$ (d, J = 8.1 Hz, 2H, H-3, H-7), 7.28 (t, J=8.6 Hz, 2H, H-4, H-6), 7.40 (m, 2H, H-10, H-14).

4-Carboxybenzylidene-4-chloroaniline (3a). Pale yellow solid, yield 69\%; m.p. $235-237{ }^{\circ} \mathrm{C}$, IR (ATR) $\mathrm{cm}^{-1} 2500-$ 3500 (O-H carboxylic acid), 3064 (C-H aromatic), 3033 $(v \mathrm{H}-\mathrm{CN}), 1675(\mathrm{C}=\mathrm{O}$ carboxylic acid $), 1620(\nu \mathrm{C}=\mathrm{N}) .{ }^{1} \mathrm{H}$ NMR: $\delta 13.24$ (s, 1H, H-15), 8.75 (s, 1H, H-8), 8.08 (d, J $=8.4 \mathrm{~Hz}, 2 \mathrm{H}, \mathrm{H}-11, \mathrm{H}-13), 7.50(\mathrm{~d}, J=8.2 \mathrm{~Hz}, 2 \mathrm{H}, \mathrm{H}-3$, $\mathrm{H}-7), 8.06$ (d, J=8.1 Hz, 2H, H-4, H-6), 7.36 (d, J=8.4 Hz, $2 \mathrm{H}, \mathrm{H}-10, \mathrm{H}-14)$.

4-Carboxybenzylidene-4-bromoaniline (4a). Pale yellow solid, yield 74\%; m.p. $266-268{ }^{\circ} \mathrm{C}$, IR (ATR) $\mathrm{cm}^{-1} 2500-$ 3500 (O-H carboxylic acid), 3061 (C-H aromatic), 3034 $(\nu \mathrm{H}-\mathrm{CN}), 1680(\mathrm{C}=\mathrm{O}$ carboxylic acid $), 1621(\nu \mathrm{C}=\mathrm{N}) .{ }^{1} \mathrm{H}$ NMR: $\delta 13.23$ (s, 1H, H-15), 8.74 (s, 1H, H-8), 8.07 (d, J $=8.7 \mathrm{~Hz}, 2 \mathrm{H}, \mathrm{H}-11, \mathrm{H}-13), 7.63(\mathrm{~d}, J=8.2 \mathrm{~Hz}, 2 \mathrm{H}, \mathrm{H}-3$, $\mathrm{H}-7), 8.05$ (d, $J=8.2 \mathrm{~Hz}, 2 \mathrm{H}, \mathrm{H}-4, \mathrm{H}-6), 7.29$ (d, $J=8.2 \mathrm{~Hz}$, 2H, H-10, H-14).

4-Carboxybenzylidene-4-methylaniline (5a). Pale yellow solid, yield 82\%; m.p. $238-240{ }^{\circ} \mathrm{C}$, IR (ATR) $\mathrm{cm}^{-1} 2500-$ 3500 (O-H carboxylic acid), 3078 (C-H aromatic), 3028 $(\nu \mathrm{H}-\mathrm{CN}), 1679(\mathrm{C}=\mathrm{O}$ carboxylic acid $), 1621(\nu \mathrm{C}=\mathrm{N}) .{ }^{1} \mathrm{H}$ NMR: $\delta 13.23$ (s, 1H, H-15), 8.73 (s, 1H, H-8), 8.14 (d, J $=8.0 \mathrm{~Hz}, 2 \mathrm{H}, \mathrm{H}-11, \mathrm{H}-13), 8.07(\mathrm{~d}, J=8.3 \mathrm{~Hz}, 2 \mathrm{H}, \mathrm{H}-3$, $\mathrm{H}-7), 8.03$ (d, J=6.0 Hz, 2H, H-4, H-6), 8.04 (d, J=5.9 Hz, $2 \mathrm{H}, \mathrm{H}-10, \mathrm{H}-14), 2.34$ (s, 3H, $\mathrm{CH}_{3}$ ).

4-Carboxybenzylidene-4-methoxyaniline (6a). Pale yellow solid, yield $82 \%$; m.p. $212-214{ }^{\circ} \mathrm{C}$, IR (ATR) $\mathrm{cm}^{-1}$ 2500-3500 (O-H carboxylic acid), 3076 (C-H aromatic), $3032(v \mathrm{H}-\mathrm{CN}), 1682(\mathrm{C}=\mathrm{O}$ carboxylic acid $), 1619(v$ $\mathrm{C}=\mathrm{N}) .{ }^{1} \mathrm{H}$ NMR: $\delta 12.63$ (s, 1H, H-15), 8.74 (s, 1H, H-8), 8.06 (d, $J=8.0 \mathrm{~Hz}, 2 \mathrm{H}, \mathrm{H}-11, \mathrm{H}-13), 7.36$ (d, $J=8.3 \mathrm{~Hz}$, $2 \mathrm{H}, \mathrm{H}-3, \mathrm{H}-7), 7.01$ (d, J=8.4 Hz, 2H, H-4, H-6), 8.02 (d, J $=7.9 \mathrm{~Hz}, 2 \mathrm{H}, \mathrm{H}-10, \mathrm{H}-14), 3.79$ (s, 3H, $\left.\mathrm{OCH}_{3}\right)$.

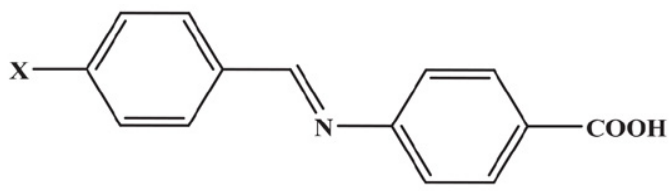

$\mathrm{X}=\mathrm{H}(\mathbf{1 b}), \mathrm{F}$ (2b), $\mathrm{Cl}$ (3b), $\mathrm{Br}(\mathbf{4 b}),-\mathrm{CH}_{3}(\mathbf{5 b}),-\mathrm{OCH}_{3}(\mathbf{6 b})$

Figure 3. Molecular structures for compounds $\mathbf{1 b}-\mathbf{6 b}$.
The compounds of 4-X-benzylidene-4-carboxyaniline (Fig. 3) were characterized as follows:

Benzylidene-4-carboxyaniline (1b). Pale yellow solid, yield 71\%; m.p. $194.8^{\circ} \mathrm{C}$, IR (ATR) $\mathrm{cm}^{-1} 2500-3500(\mathrm{O}-\mathrm{H}$ carboxylic acid), 3068 (C-H aromatic), $3031(v \mathrm{H}-\mathrm{CN})$, $1677\left(\mathrm{C}=\mathrm{O}\right.$ carboxylic acid), $1622(v \mathrm{C}=\mathrm{N}) .{ }^{1} \mathrm{H}$ NMR: $\delta 12$. 83 (s, 1H, H-15), 8.65 (s, 1H, H-8), 7.97 (d, J=8.3 Hz, 2H, $\mathrm{H}-11, \mathrm{H}-13), 7.56$ (d, J = 7.5 Hz, 2H, H-3, H-7), 7.37-730 (m, 2H, H-4, H-6), 7.58 (d, J = 8.1 Hz, 2H, H-10, H-14), 7.37-7.30 (m, 1H, H-5).

4-Fluorobenzylidene-4-carboxyaniline (2b). Pale yellow solid, yield 88\%; m.p. $249^{\circ} \mathrm{C}$, IR (ATR) $\mathrm{cm}^{-1} 2500-3500$ (O-H carboxylic acid), 3071 (C-H aromatic), $3019(\nu \mathrm{H}-$ $\mathrm{CN}), 1678$ (C=O carboxylic acid), $1625(\nu \mathrm{C}=\mathrm{N}) .{ }^{1} \mathrm{H}$ NMR: $\delta 12.35$ (s, 1H, H-15), 8.64 (s, $1 \mathrm{H}, \mathrm{H}-8), 7.99$ (d, $J=8.5 \mathrm{~Hz}$, 2H, H-11, H-13), 7.32 (d, J = 8.0 Hz, 2H, H-3, H-7), 7.45 $(\mathrm{t}, J=8.6 \mathrm{~Hz}, 2 \mathrm{H}, \mathrm{H}-4, \mathrm{H}-6), 7.62$ (d, $J=8.2 \mathrm{~Hz}, 2 \mathrm{H}, \mathrm{H}-10$, H-14).

4-Chlorobenzylidene-4-carboxyaniline (3b). Pale yellow solid, yield 79\%; m.p. $270.4{ }^{\circ} \mathrm{C}$, IR (ATR) cm $\mathrm{cm}^{-1} 2500-3500$ (O-H carboxylic acid), 3073 (C-H aromatic), $3013(v \mathrm{H}-$ $\mathrm{CN}), 1677$ (C=O carboxylic acid), $1624(\nu \mathrm{C}=\mathrm{N}) .{ }^{1} \mathrm{H}$ NMR: $\delta 12.38$ (s, 1H, H-15), 8.66 (s, 1H, H-8), 7.98 (d, $J=8.1$ Hz, 2H, H-11, H-13), 7.33 (d, $J=7.6$ Hz, 2H, H-3, H-7), $7.93(\mathrm{~d}, J=8.0 \mathrm{~Hz}, 2 \mathrm{H}, \mathrm{H}-4, \mathrm{H}-6), 7.61$ (d, $J=7.9 \mathrm{~Hz}, 2 \mathrm{H}$, H-10, H-14).

4-Bromobenzylidene-4-carboxyaniline (4b). Pale yellow solid, yield 80\%; m.p. $289^{\circ} \mathrm{C}$, IR (ATR) $\mathrm{cm}^{-1} 2500-3500$ (O-H carboxylic acid), 3070 (C-H aromatic), $3018(\nu \mathrm{H}-$ $\mathrm{CN}), 1679(\mathrm{C}=\mathrm{O}$ carboxylic acid $), 1621(\nu \mathrm{C}=\mathrm{N}) .{ }^{1} \mathrm{H}$ NMR: $\delta 12.33$ (s, 1H, H-15), 8.66 (s, 1H, H-8), 7.99 (d, $J=8.1$ $\mathrm{Hz}, 2 \mathrm{H}, \mathrm{H}-11, \mathrm{H}-13), 7.34$ (d, $J=8.0 \mathrm{~Hz}, 2 \mathrm{H}, \mathrm{H}-3, \mathrm{H}-7)$, $7.91(\mathrm{~d}, J=8.1 \mathrm{~Hz}, 2 \mathrm{H}, \mathrm{H}-4, \mathrm{H}-6), 7.62$ (d, $J=8.2 \mathrm{~Hz}, 2 \mathrm{H}$, H-10, H-14).

4-Methylbenzylidene-4-carboxyaniline (5b). Pale yellow solid, yield 74\%; m.p. $256.2^{\circ} \mathrm{C}$, IR (ATR) $\mathrm{cm}^{-1} 2500-3500$ (O-H carboxylic acid), 3070 (C-H aromatic), $3032(v \mathrm{H}-$ $\mathrm{CN}), 1678$ (C=O carboxylic acid), $1627(\nu \mathrm{C}=\mathrm{N}) .{ }^{1} \mathrm{H}$ NMR: $\delta 12.50$ (s, 1H, H-15), 8.59 (s, 1H, H-8), 7.98 (d, $J=8.1 \mathrm{~Hz}$, 2H, H-11, H-13), 7.35 (d, J = 7.7 Hz, 2H, H-3, H-7), 7.31 $(\mathrm{d}, J=8.0 \mathrm{~Hz}, 2 \mathrm{H}, \mathrm{H}-4, \mathrm{H}-6), 7.86$ (d, $J=7.7 \mathrm{~Hz}, 2 \mathrm{H}, \mathrm{H}-10$, $\mathrm{H}-14), 2.39$ (s, 3H, $\mathrm{CH}_{3}$ ).

4-Methoxybenzylidene-4-carboxyaniline (6b). Pale yellow solid, yield $72 \%$; m.p. $289^{\circ} \mathrm{C}$, IR (ATR) $\mathrm{cm}^{-1} 2500$ 3500 (O-H carboxylic acid), 3063 (C-H aromatic), 3030 ( $v \mathrm{H}-\mathrm{CN}), 1678\left(\mathrm{C}=\mathrm{O}\right.$ carboxylic acid), $1626(\nu \mathrm{C}=\mathrm{N}) .{ }^{1} \mathrm{H}$ NMR: $\delta 12.61$ (s, 1H, H-15), 8.55 (s, 1H, H-8), 7.97 (d, J $=8.2 \mathrm{~Hz}, 2 \mathrm{H}, \mathrm{H}-11, \mathrm{H}-13), 7.29(\mathrm{~d}, J=8.1 \mathrm{~Hz}, 2 \mathrm{H}, \mathrm{H}-3$, $\mathrm{H}-7$ ), 7.09 (d, $J=8.3 \mathrm{~Hz}, 2 \mathrm{H}, \mathrm{H}-4, \mathrm{H}-6), 7.91$ (d, $J=8.2 \mathrm{~Hz}$, $2 \mathrm{H}, \mathrm{H}-10, \mathrm{H}-14), 3.85$ (s, 3H, $\mathrm{OCH}_{3}$ ). 


\section{Results and Discussion}

\section{1. Synthesis}

Target Schiff bases were synthesized by the condensation reactions of aromatic aldehydes and aromatic amines using absolute ethanol as the solvent and glacial acetic acid as the catalyst. Compounds 1a-6a were synthesized by the reaction of 4-formylbenzoic acid with 4-sub- stituted aniline. Compounds $\mathbf{1} \mathbf{b}-\mathbf{6} \mathbf{b}$ were synthesized by the reaction of 4 -amino benzoic acid with 4 -substituted benzaldehyde (Scheme 1).

\section{2. Characterization}

FT IR spectra for compounds $\mathbf{1 a}-\mathbf{6 a}$ and $\mathbf{1 b}-\mathbf{6 b}$ showed the absence of $\mathrm{NH}_{2}$ group stretching vibration
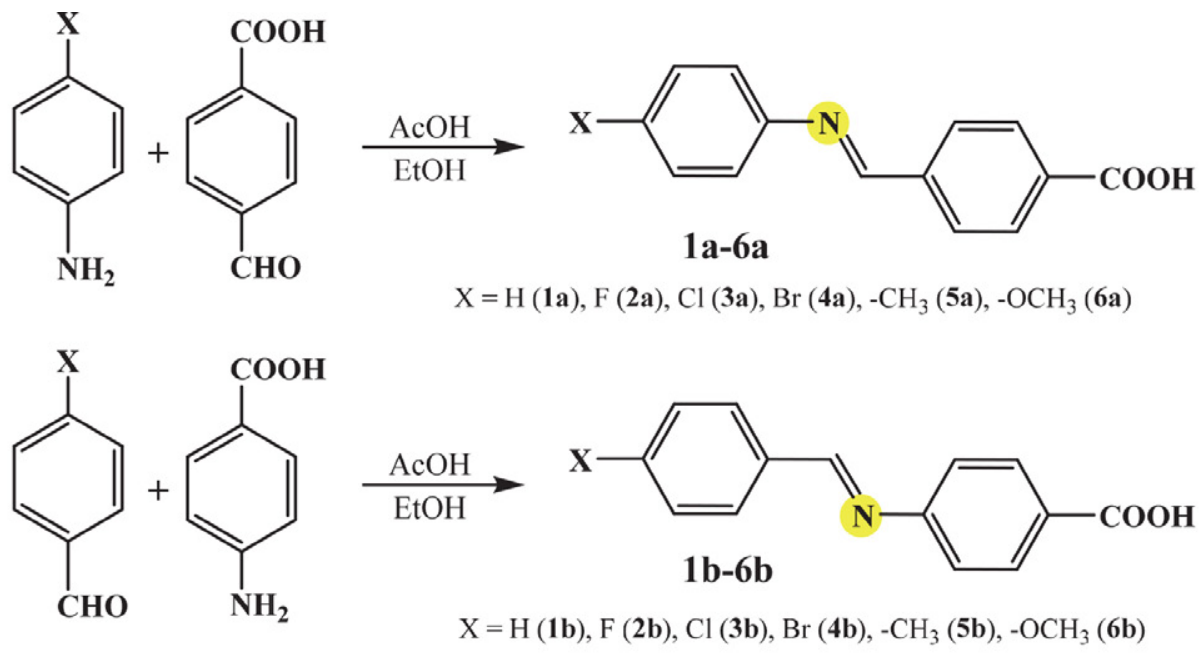

Scheme 1. Synthetic route for compounds $1 \mathbf{a}-\mathbf{6 a}$ and $\mathbf{1 b}-\mathbf{6 b}$.
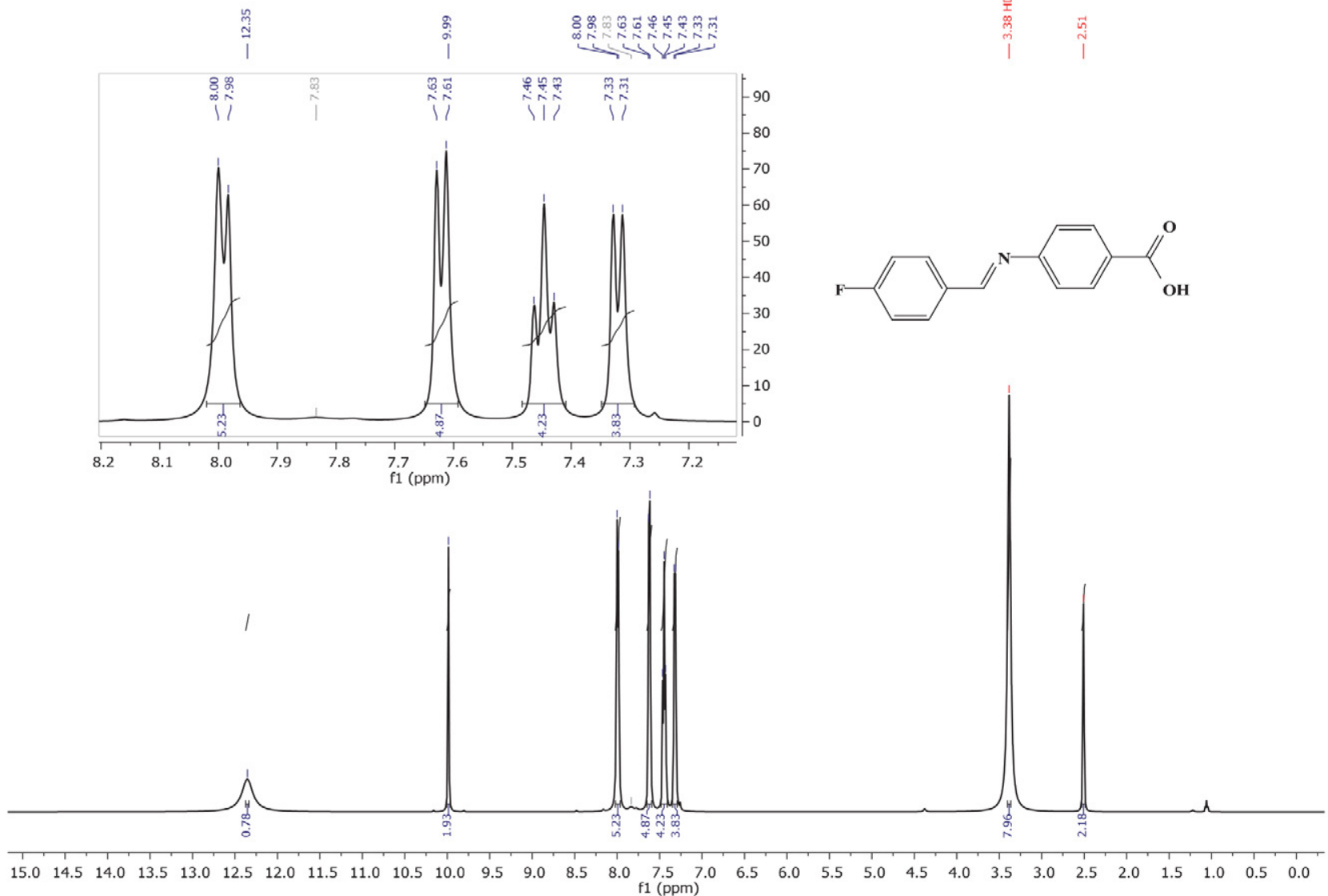

Figure 4. ${ }^{1} \mathrm{H}$ NMR spectrum of compound $\mathbf{2 b}$. 

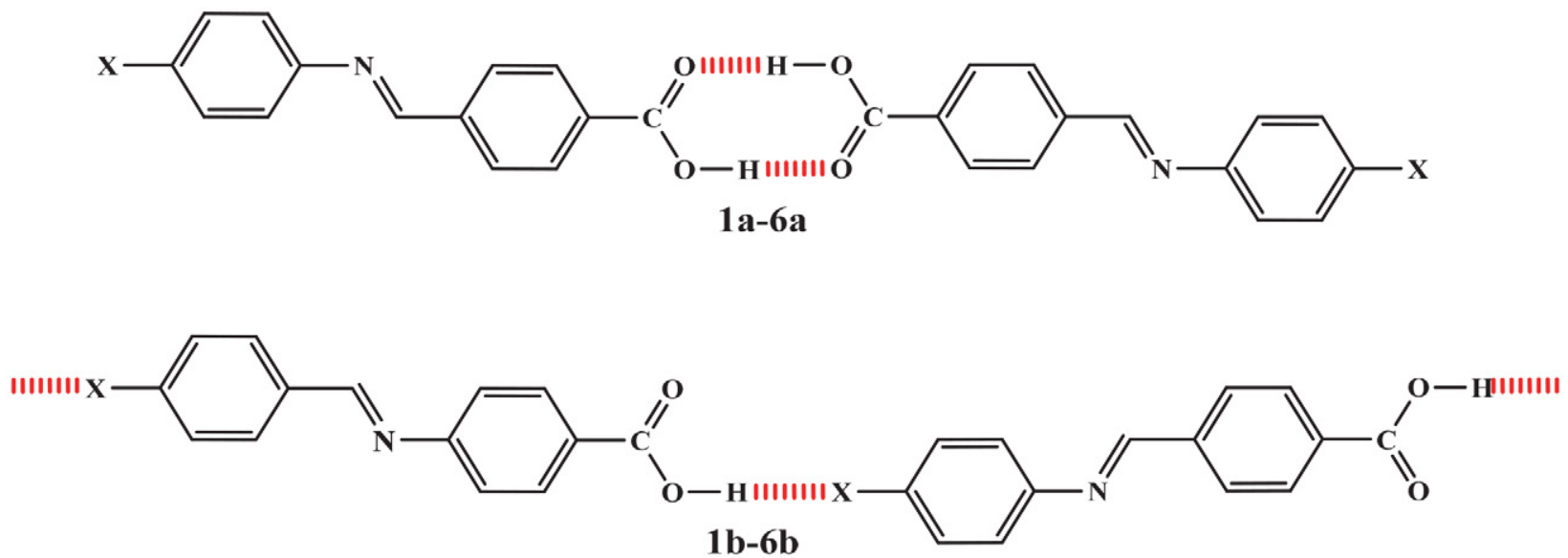

Figure 5. A schematic of the hydrogen bond in compounds 1a-6a and 1b-6b.

bands for aromatic amine and $v \mathrm{C}=\mathrm{O}$ group absorption band for aromatic aldehyde. FT IR spectra for compounds 1a-6a revealed a broad absorption within the range $2500-3500 \mathrm{~cm}^{-1}$ which is attributable to the $\mathrm{O}-\mathrm{H}$ group, medium absorption within the range 3057-3078 $\mathrm{cm}^{-1}$ attributable to the aromatic $\mathrm{C}-\mathrm{H}$, strong absorption band within the range $1675-1682 \mathrm{~cm}^{-1}$ attributable to the $\mathrm{C}=\mathrm{O}$ group of carboxylic acid, and absorption within the range $1619-1621 \mathrm{~cm}^{-1}$ for the $\mathrm{C}=\mathrm{N}$ group. FT IR spectra for compounds $\mathbf{1} \mathbf{b}-\mathbf{6} \mathbf{b}$ showed the appearance of a broad absorption band within the range $2500-3500 \mathrm{~cm}^{-1}$ attributable to the $\mathrm{O}-\mathrm{H}$ group, an absorption band within a range $3063-3073 \mathrm{~cm}^{-1}$ that was attributable to aromatic $\mathrm{C}-\mathrm{H}$, and a strong absorption band within the range $1677-1679 \mathrm{~cm}^{-1}$ that was attributable to $\mathrm{C}=\mathrm{O}$ group of carboxylic acid, besides absorption band for $\mathrm{C}=\mathrm{N}$ group observed within the range $1621-1627 \mathrm{~cm}^{-1}$. Further identification for Schiff bases was performed using ${ }^{1} \mathrm{H}$ NMR, spectra of compounds 1a-6a were comprised of a singlet signal within the range 12.63-13.24 ppm attributed to the proton of the hydroxyl group $(-\mathrm{COO} \underline{\mathrm{H}})$; a singlet signal at the down-field region within the range 8.73-8.75 ppm which evidenced the presence of the proton of the azomethine group $(\underline{\mathrm{H}}-\mathrm{C}=\mathrm{N})$ and several different signals within the range 7.01-8.14 ppm which are ascribed to aromatic protons. ${ }^{1} \mathrm{H}$ NMR spectra for compounds $\mathbf{1 b}-\mathbf{6} \mathbf{b}$ showed a singlet signal within the range $12.35-12.83 \mathrm{ppm}$ which is ascribed to the proton of the hydroxyl group $(-\mathrm{COOH})$; a singlet signal within the range $8.55-8.66 \mathrm{ppm}$ which was attributed to the proton of the azomethine group $(\mathrm{H}-$ $\mathrm{C}=\mathrm{N}$ ); and several signals within the range 7.29-7.99 ppm which were attributed to aromatic protons. The ${ }^{1} \mathrm{H}$ NMR spectrum for compound $\mathbf{2 b}$ is shown in Fig. 4 as a representative illustration.

Chemical shift values (12.63-13.24 ppm) for the proton of the hydroxyl group in compounds 1a-6a suggest that these compounds tend to form stabilized dimers by hydrogen bonding between carboxyl groups, while the chemical shift values (12.63-13.24 ppm) for compounds $\mathbf{1 b}-\mathbf{6 b}$ suggest that these compounds prefer to form weak hydrogen bonds between the carboxyl group and terminal substituent groups on the benzylidene ring (Fig. 5).

\section{3. A Study of the Mesomorphic Properties of the Synthesized Compounds}

Polarised optical microscopy and differential scanning calorimetry were used to study the mesomorphic properties of synthesized compounds, employing careful monitoring by POM during heating and cooling scans and subsequently verified by the DSC measurements. The results showed that there are no mesomorphic properties for compounds 1a-6a, owing to spontaneous carboxylic dimerization via intermolecular hydrogen bonding and weakness in the lateral attractive force (Fig. 5). On the other hand, it was found that the melting points of these compounds increase as the terminal halogen atom size increased (Fig. 6).

Mesomorphic properties of synthesized compounds $\mathbf{1 b}-\mathbf{6 b}$ were investigated by DSC and POM and the measurements were very similar. Transition temper-

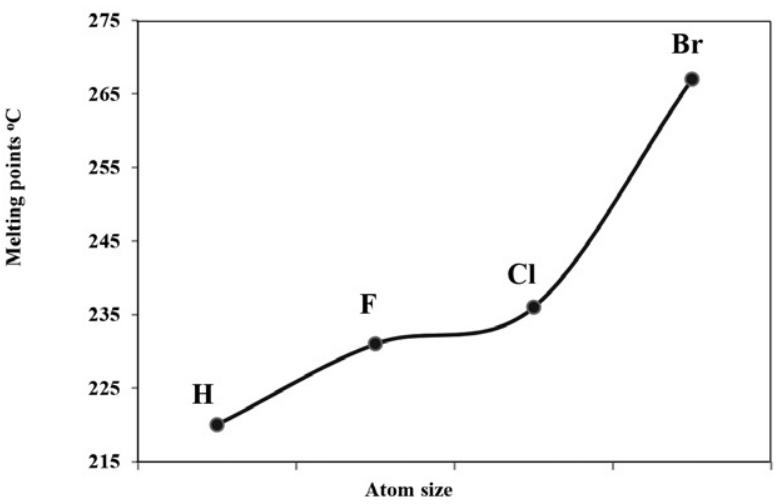

Figure 6. The dependence of melting points on the size of substituent atoms. 
Table1. Mesomorphic data and structures for compounds $\mathbf{1 b}-\mathbf{6 b}$

\begin{tabular}{lcccccc}
\hline Comp. & Transition & $\begin{array}{c}\text { Peak temp. } \\
{ }^{\circ} \mathbf{C}\end{array}$ & $\mathbf{D} \boldsymbol{T}_{\mathbf{S m}}$ & $\mathbf{D} \boldsymbol{T}_{\mathbf{N}}$ & $\begin{array}{c}\boldsymbol{\Delta H} \\
\left(\mathbf{k J ~ m o l}^{-\mathbf{1}} \mathbf{)}\right.\end{array}$ & $\begin{array}{c}\boldsymbol{\Delta} \boldsymbol{H} \\
\left(\mathbf{J ~ m o l}^{-\mathbf{1}} \mathbf{K}^{-\mathbf{1}} \mathbf{)}\right.\end{array}$ \\
\hline $\mathbf{1 b}$ & $\mathrm{Cr}-\mathrm{I}$ & 197.4 & - & - & - & - \\
& $\mathrm{Cr}-\mathrm{Sm}$ & 166 & & & 0.2531 & 0.5766 \\
$\mathbf{2 b}$ & $\mathrm{Sm}-\mathrm{N}$ & 197.7 & 31.7 & 70.6 & 7.7838 & 16.5365 \\
& $\mathrm{~N}-\mathrm{I}$ & 268.3 & & & 9.1891 & 16.9760 \\
& $\mathrm{Cr}-\mathrm{Sm}$ & 224 & & & 1.5491 & 3.1166 \\
$\mathbf{3 b}$ & $\mathrm{Sm}-\mathrm{N}$ & 263.5 & 39.5 & 14.5 & 2.8153 & 5.2475 \\
& $\mathrm{~N}-\mathrm{I}$ & 278 & & & 2.5721 & 4.6680 \\
& $\mathrm{Cr}-\mathrm{Sm}$ & 225.2 & & & 1.4613 & 2.9332 \\
$\mathbf{4 b}$ & $\mathrm{Sm}-\mathrm{N}$ & 247.9 & 22.7 & 28.1 & 1.0373 & 1.9913 \\
& $\mathrm{~N}-\mathrm{I}$ & 276 & & & 0.8338 & 1.5186 \\
$\mathbf{5 b}$ & $\mathrm{Cr}-\mathrm{N}$ & 242.1 & & 24.2 & 7.3093 & 14.1900 \\
& $\mathrm{~N}-\mathrm{I}$ & 266.3 & & & 7.3193 & 13.5718 \\
$\mathbf{6 b}$ & $\mathrm{Cr}-\mathrm{N}$ & 202.9 & & 88.9 & 8.7821 & 18.4535 \\
& $\mathrm{~N}-\mathrm{I}$ & 291.8 & & & 1.0423 & 1.8454 \\
\hline
\end{tabular}

atures and associated $\Delta H, \Delta S$ are listed in Table 1 . The investigation revealed no mesomorphic behavior for compound $\mathbf{1 a}$, whereas, compounds $\mathbf{2 b}-\mathbf{4 b}$ were dimorphic exhibiting smectic and nematic phase, furthermore, compounds $\mathbf{5 b}$ and $\mathbf{6 b}$ were monomorphic exhibiting nematic phase. Smectic mosaic and nematic Schlieren textures were observed during POM investigation, optical photomicrographs are shown in Fig. 7 and the DSC thermogram of $\mathbf{6 b}$ is shown in Fig. 8 as a representative illustration.

\section{5. Influence of Reverse Imine Linkage on Mesomorphic Properties}

Despite the structural similarity of compounds $\mathbf{1 a}-\mathbf{6 a}$ and $\mathbf{1 b}-\mathbf{6 b}$, the mesomorphic properties are quite
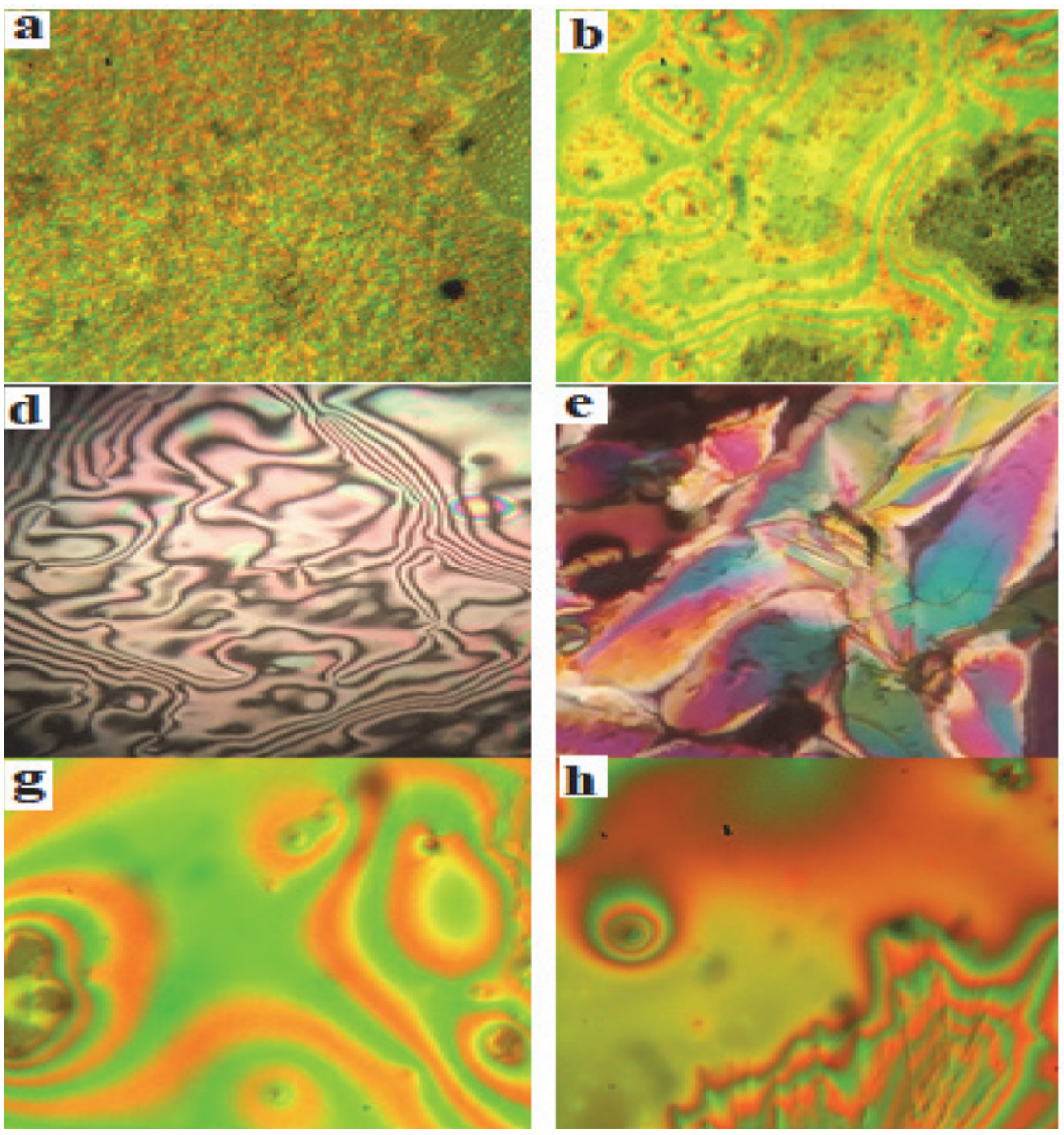

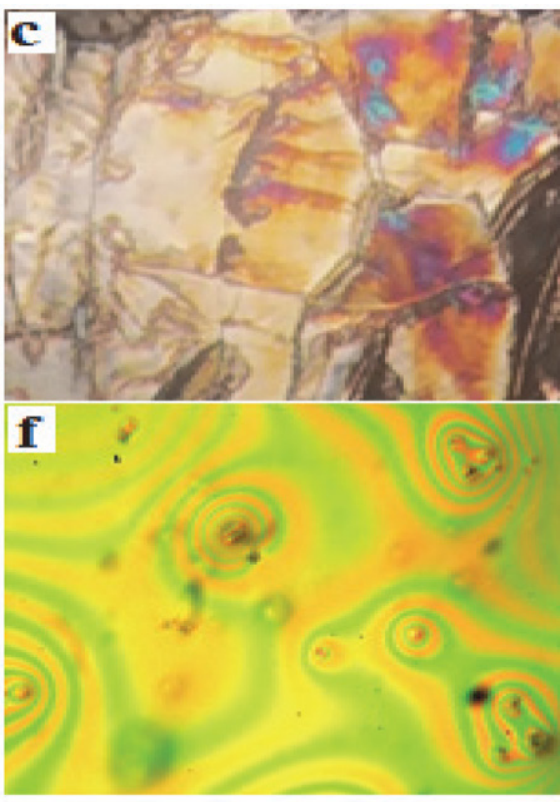

Figure 7. Polarized optical micrographs for: (a) compound $\mathbf{2 b}$ (smectic at $166^{\circ} \mathrm{C}$ ); (b) compound $\mathbf{2 b}$ (nematic, Schlieren at 197.7 $\left.{ }^{\circ} \mathrm{C}\right)$; (c) compound $\mathbf{3 b}$ ( smectic at $224^{\circ} \mathrm{C}$ ), (d) compound 3b (nematic, Schlieren at 263.5 ${ }^{\circ} \mathrm{C}$ ); (e) compound $\mathbf{4 b}$ (smectic at $225.2{ }^{\circ} \mathrm{C}$ ); (f) compound $\mathbf{4 b}$ (nematic, Schlieren at 247.9 $\left.{ }^{\circ} \mathrm{C}\right)$; (g) compound $\mathbf{5 b}$ (nematic, Schlieren at $242.1{ }^{\circ} \mathrm{C}$ ); (h) compound $\mathbf{6 b}$ (nematic, Schlieren at $202.9^{\circ} \mathrm{C}$ ). 


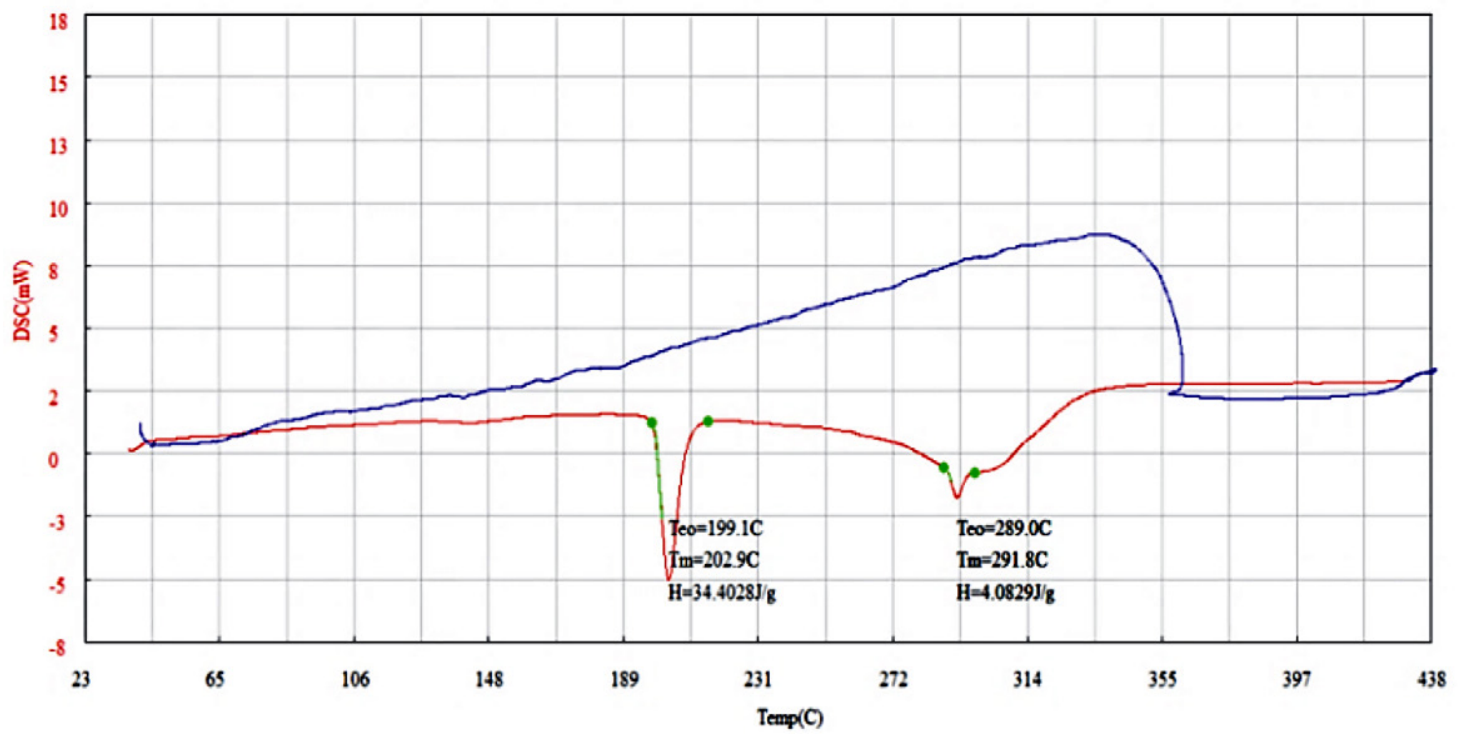

Figure 8. DSC thermogram for compound $\mathbf{6 b}$.

different. No mesomorphic properties were found for compounds 1a-6a, while inversions of imine linkage orientation in compounds $\mathbf{1 b}-\mathbf{6 b}$ enhanced the mesomorphic properties, except for compound $\mathbf{1 b}$ due to the absence of a terminal group (in $\mathbf{1 b}$ ) and its dimerization by intermolecular hydrogen bonding. Orientations of inverted imine linkage and carboxyl group beside terminal substituents cause remarkable changes on the dipole moment and improve the polarisability of the molecule by conju-

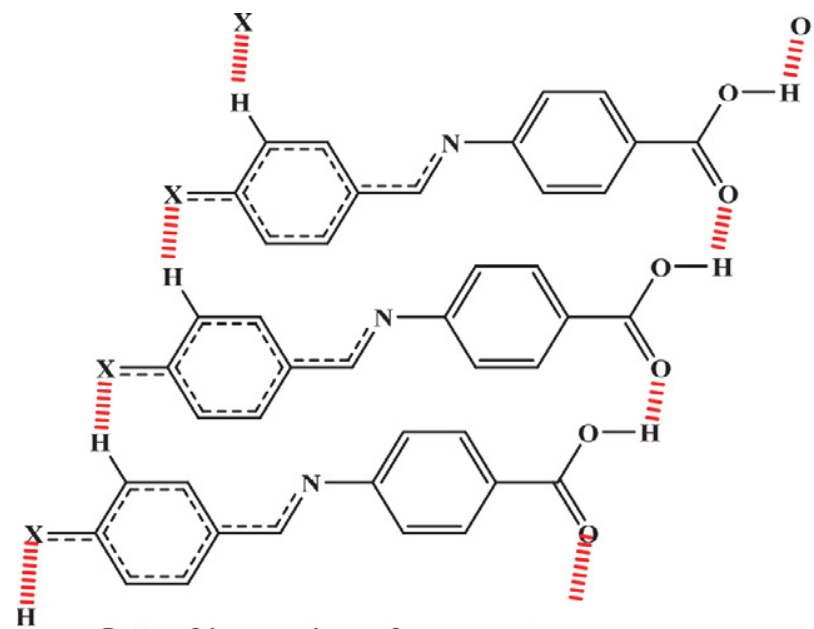

gation between azomethine and terminal substituents via the phenyl ring for compounds $\mathbf{2 b}-\mathbf{4 b}$, thus, increasing the lateral attraction force to enhance the formation of smectic phase and terminal attraction force by hydrogen bonding to enhanced nematic phase formation ${ }^{11}$ (Fig. 9).

The appearance of the nematic phase in compounds $\mathbf{5 b}$ and $\mathbf{6 b}$ was enhanced by the terminal hydrogen bonding between carboxyl and a $\pi$ orbital created by hyperconjugation, ${ }^{12}$ while in compound $\mathbf{6 b}$ hydrogen bonding was between carboxyl group and the oxygen atom of the methoxy group (Fig. 10).

\section{Conclusion}

Benzylidene aniline compounds were synthesized and characterized. The study indicates that the hydrogen bonding and the orientation of inverted imine $\mathrm{C}=\mathrm{N}$ linkage play a significant role in liquid crystals behavior, especially in compounds $\mathbf{1 a - 6 a}$ and $\mathbf{1 b}$, which is preventing the formation of liquid crystals owing to their dimerization through hydrogen bonding, while the liquid crystal properties of compounds $\mathbf{2 b}-\mathbf{6 b}$ were improved by the lateral interactions and terminal hydrogen bonding occurring between carboxyl and terminal substituent group.

Lateral interaction enhancement by hydrogen bond

Figure 9. Hydrogen bonds for compounds $\mathbf{2 b}-\mathbf{4 b}$ at the smectic and nematic phases. 

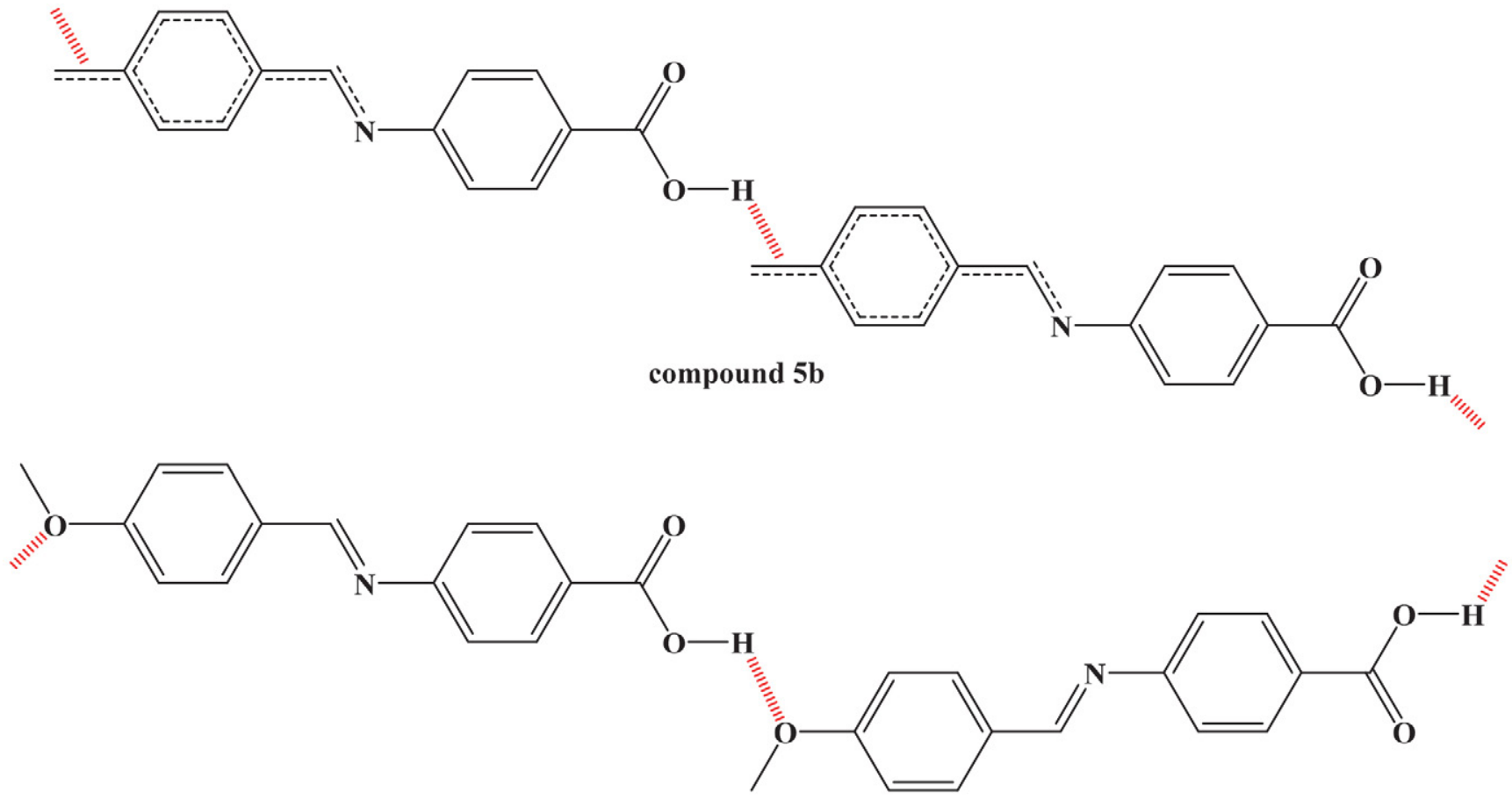

compound $6 b$

Figure 10. Hydrogen bond for compounds $5 \mathbf{b}$ and $\mathbf{6 b}$ at the nematic phase.

\section{Acknowledgments}

The author is grateful to Ms. Alaa Adnan Rashad, Al-Nahrain University, for her help in carrying out some of the measurements in this research.

\section{References}

1. B. Bai, H. Wang, H. Xin, B. Long, M. Li, Liq. Cryst. 2007, 34, 659-665. DOI:10.1080/02678290701328118

2. T. Steiner, Angew. Chem. Int. Ed. 2002, 41, 48-76.

DOI:10.1002/1521-3773(20020104)41:1<48::AID-ANIE48 >3.0.CO;2-U

3. E. Arunan, G. R. Desiraju, R. A. Klein, J. Sadlej, S. Scheiner, I. Alkorta, D. C. Clary, R. H. Crabtree, J. J. Dannenberg, P. Hobza, H. G. Kjaergaard, A. C. Legon, B. Mennucci, D. J. Nesbitt, Pure Appl. Chem. 2011, 83, 1637-1641.

DOI:10.1351/PAC-REC-10-01-02

4. G. W. Gray, B. Jones, J. Chem. Soc. 1954, 2556-2562.

DOI:10.1039/jr9540002556

5. Y. Arakawa, Y. Sasaki, K. Igawa, H. Tsuji, New J. Chem. 2017, 41, 6514-6522. DOI:10.1039/C7NJ00282C

6. T. Kato, J. M. J. Frechet, J. Chem. Soc. 1989, 111, 8533-8534. DOI:10.1021/ja00204a044

7. T. Kato, J. M. J. Frechet, P. G. Wilson, T. Saito, T. Uryu, A. Fujishima, C. Jin, F. Kaneuchi, Chem. Mater. 1993, 5, 10941100. DOI:10.1021/cm00032a012
8. T. Kato, A. Fujishima, J. M. J. Frechet, Chem. Lett.1990, 19, 919-922. DOI:10.1246/cl.1990.919

9. M. Fourmigué, Curr. Opin. Solid State Mater. Sci. 2009, 13, 36. DOI:10.1016/j.cossms.2009.05.001

10. B. Bankiewicz, M. Palusiak, Struct. Chem. 2013, 24, 12971306. DOI:10.1007/s11224-012-0157-1

11. H. L. Nguyuen, P. N. Horton, M. B. Hursthouse, A. C. Legon, D. W. Bruce, J. Am. Chem. Soc. 2004, 126, 16-17. DOI:10.1021/ja036994l

12. H. B. Bürgi, J. D. Dunitz, Helv. Chim. Acta, 1970, 53, 17471764. DOI:10.1002/hlca.19700530724

13. L. Óvári, Y. Luo, F. Leyssner, R. Haag, M. Wolf, P. Tegeder, J. Chem. Phys. 2010, 133, 1-8. DOI:10.1063/1.3460647 


\section{Povzetek}

$\mathrm{V}$ tej študiji smo raziskali učinke substituentov in vodikovih vezi ter orientacije iminskih povezav na obnašanje benziliden anilinskih spojin v vlogi tekočih kristalov (LC). 4-Karboksibenziliden-4-X-aniline (X = H, F, Cl, Br, $\mathrm{CH}_{3}, \mathrm{OCH}_{3}$ ) 1a-6a smo sintetizirali s pomočjo reakcije anilina in njegovih substituiranih derivatov s 4-formilbenzojsko kislino; 4-X-benziliden-4-karboksi aniline $\left(\mathrm{X}=\mathrm{H}, \mathrm{F}, \mathrm{Cl}, \mathrm{Br}, \mathrm{CH}_{3}, \mathrm{OCH}_{3}\right) \mathbf{1 b}-\mathbf{6 b}$ pa smo pripravili z reakcijo anilina in njegovih substituiranih derivatov s 4-aminobenzojsko kislino v absolutnem etanolu kot topilu. Pripravljene spojine smo karakterizirali s pomočjo FT IR in ${ }^{1} \mathrm{H}$ NMR spektroskopije, lastnosti tekočih kristalov pa smo raziskali s pomočjo diferenčne dinamične kalorimetrije (DSC) in s polarizirano optično mikroskopijo (POM). Glede na mezomorfne lastnosti smo dokazali, da so spojine $\mathbf{2 b}-\mathbf{4 b}$ dimorfne in izkazujejo smektično in nematično fazo, spojini $\mathbf{5 b}, \mathbf{6 b}$ sta monofazni in izkazujeta nematično fazo, spojine $\mathbf{1 a}-\mathbf{6 a}$ and $\mathbf{1 b}$ pa niso pokazale mezofaznega obnašanja. Pri spojinah 1a-6a se zaradi vodikovih vezi in inverzne iminske povezave (glede na spojine $\mathbf{1 b}-\mathbf{6 b}$ ) mezofazne lastnosti niso pojavile.

Except when otherwise noted, articles in this journal are published under the terms and conditions of the Creative Commons Attribution 4.0 International License 